\title{
Aggregate Supply Response of Some Livestock Commodities in Algeria: Cointegration-VECM Approach
}

\author{
Amine M. Benmehaia, Amine Oulmane
}

\begin{abstract}
The supply response of agricultural commodities to changes in price incentives is an important issue for the success of any policy reform in the agricultural sector. This study aims to quantify the responsiveness of producers of some livestock commodities to price incentives in Algerian context. Time series analysis is used on annual data for a period of 52 years (1966-2018). Both co-integration and vector error correction model (VECM) are used through the Nerlove model of partial adjustment. The study attempts to determine the long-run and short-run relationships along with the magnitudes of disequilibria in the selected commodities. Results show that the short-run price elasticities are low in cow and sheep meat sectors ( 8.7 and $8 \%$ respectively), while their respective long-run elasticities are 16.5 and 10.5, whereas eggs and milk have very high short-run price elasticities ( 82 and $90 \%$ respectively) with long-run elasticities of 40 and 46 respectively. The error correction coefficient, reflecting the speed of adjustment towards the long-run equilibrium, is statistically significant and have the expected negative sign. Its estimates are 12.7 for cow meat, 33.5 for sheep meat, 46.7 for eggs and 8.4 for milk. It seems that cow meat and milk producers have a weak feedback of about $12.7 \%$ and $8.4 \%$ respectively of the previous year's disequilibrium from the long-run price elasticity, whereas sheep meat and eggs producers adjust to correct long run disequilibrium with a high speed of adjustment (33.5\% and $46.7 \%$ respectively). The implication of this is that much more in-depth research is needed to identify those factors that affect agricultural supply and to describe the effect of factors that shift supply in response to price incentives. This could provide valuable information for government in the use of appropriate policy measures.
\end{abstract}

Keywords-Algeria, cointegration, livestock, supply response, vector error correction model.

\section{INTRODUCTION}

One of the most important issues in agricultural development economics is the supply response since the responsiveness of farmers to economic incentives largely determines agriculture's contribution to the economy [1]. In Algeria, agriculture has made a quantitatively remarkable growth after initiation of new agricultural strategy in 2000. Algerian agriculture has progressed not only in output and yield terms but relatively some structural changes have also contributed. Government provided more incentives such as remunerative prices to protect farmers' interest, improving irrigation facilities, improving markets of output, to farmers to

A.M. Benmehaia is with the Department of Agricultural Sciences, University of Biskra, Algeria.

A. Oulmane is with Research Center in Applied Economics for Development (CREAD), Algeria. produce more. After these changes, it is expected that farmers would become more price responsive.

One of the major disturbing phenomena in Algeria today is the shortage of food livestock products (especially dairy products) with the attendant result of soaring prices and rising importation of these commodities with high dependency on international inputs markets. This shortage can be attributed to a number of factors among which are the increase in population which is not matched by the rate of growth in the food production and poor storage system. Food shortage and subsequent rise in price of food items is experienced in Algeria due to a number of other problems facing livestock farmers in general. These problems range from high cost of production as a result of increase in price of input, low return from the enterprise in terms of income, low efficiency of resource utilization, lack of capital and scarcity of improved materials which is capable of giving higher yields. Added to this myriad of problems is the price fluctuation caused by seasonality of production, poor storage infrastructures, unsteady market structures and unstable government trade policies.

Studies on supply response in the Algerian agriculture are quasi-absent. The study of Ghafouri [2] and Benmehaia [3] are concerned with some crop production, whereas the study of Benmehaia and Oulmane [4] is especially concerned with potato sector. There has been no focus on the supply response in livestock production. Thus, the present study is an attempt to re-examine supply response in the Algerian livestock production through an econometric approach. Co-integration and error-correction techniques are applied. The question raised here is: to what extent the livestock farmers' supply is responsive for price incentives in Algerian agriculture. There is empirical evidence that the dynamics of supply can be better described by Error-Correction Models (ECM) than Partial Adjustment Models [5] [6] [7]. Cointegration and ECMs have been used in agricultural supply response analysis in other countries by a number of researchers, namely [8] [6] [9].

\section{MATERIALS AND METHODS}

The data set begins in 1966 and ends in 2018. It was obtained from the Food and Agriculture Organization's statistical database (FAO). The data were indexed at the 2010 prices and converted to logarithms in order easily to interpret coefficients of interest as elasticities.

Each of the series is tested for the presence of a unit root by 
estimating an Augmented Dickey Fuller (ADF) test both with and without the deterministic trend. After verifying that variables are stationary or not, we took first lag difference of all series and again estimated ADF equation both with and without the deterministic trend. The final stage is to test for cointegration. We test for cointegration by using EngleGranger two-step procedure. In this approach, first we estimated long-run relationship if all variables are integrated in same order and obtained residuals. The residuals of this relationship is tested for the presence of a unit root. If the test reported presence of unit root in residuals, the variables used in long-run relationship are not cointegrated and if the test rejected null hypothesis, the variables used in long-run relationship are cointegrated. If the variables under consideration are integrated of order one, or I(1), the error term from the co-integrating relationship should be integrated of order zero, $\mathrm{I}(0)$, implying that any drift between variables in the short run is temporary and that equilibrium holds in the long run. These techniques are believed to overcome the problem of spurious regressions and to give consistent and distinct estimates of long-run and short-run elasticities that satisfy the properties of the classical regression procedure [7].

The long-run supply response is estimated using variables indicated in the following equation:

$$
Y_{t}=\alpha P_{t-1}+\beta T+\epsilon_{t}
$$

where $Y_{t}$ is the dependent variable representing quantity produced at time $t, P_{t}$ represents a vector of own prices which is interpreted as the long run price elasticity of supply, $T$ stands for time trend which allows to capture the effects of infrastructure development and different technological advances, and $\varepsilon$ represents the error term.

The ECM model is estimated by the equation below:

$$
\Delta Y_{t}=\delta \Delta P_{t}+\theta T+\lambda \epsilon_{t-1}+\varepsilon_{t}
$$

where $\Delta$ represents first differencing operator, $\lambda$ measures the extent of correction of errors by adjustment in $Y_{t}$., and $\delta$ measures the short-run effect on supply of a per cent change in own price (or short-run price elasticity of supply).

\section{RESULTS AND DISCUSSION}

The unit root test using the Augmented Dickey Fuller (ADF) are presented in Table I. It shows that all the variables were non-stationary in their levels but were stationary at first differences. The test used the critical values for the rejection of the null hypothesis of no unit root. This indicated that the variables were I(1) and any attempt to specify the dynamic function of the variable in the level of the series will be inappropriate and may lead to spurious results in the long-run analysis. Therefore, the test of co-integration was applied to the series data which were integrated in the same order I(1) but did not have a unit root.

The Johansen's co-integration test showed the presence of co-integrating equations at $5 \%$ level of significance implying a common trend in the process (Table II). The cointegration tests were to test whether there was a statistical significant linear relationship between the different time series data. Test statistics from the maximum Eigen value are consistent in suggesting that there are two integrating vectors among the variables. This suggested that the explanatory variables were co-integrated and had both short run and long run relationships with the dependent variable. Both the tests confirm that there are at least two cointegrating vectors at the $95 \%$ significance level.

TABLE I

AUGMENTED DICKEY-FULLER TESTS OF PRODUCTION AND

\begin{tabular}{|c|c|c|}
\hline & With constant & "With constant and trend \\
\hline \multicolumn{3}{|c|}{ Cow meat } \\
\hline$\overline{\mathrm{Y}}$ & $-0.016(-0.22)$ & $-0.236(-2.75)$ \\
\hline$\Delta \mathrm{Y}$ & $-0.862(-4.34) * * *$ & $-0.978(-4.72) * * *$ \\
\hline $\mathrm{P}$ & $-0.065(-0.65)$ & $-1.804(-2.16)$ \\
\hline$\Delta \mathrm{P}$ & $-3.913(-6.56) * * *$ & $-3.933(-6.43) * * *$ \\
\hline \multicolumn{3}{|c|}{ Sheep meat } \\
\hline $\mathrm{Y}$ & $-1.191(-5.88)$ *** & $-2.231(-3.64) * * *$ \\
\hline$\Delta \mathrm{Y}$ & $-3.817(-3.98) * * *$ & $-3.777(-4.05) * * *$ \\
\hline $\mathrm{P}$ & $-0.078(-1.18)$ & $-0.316(-2.07)$ \\
\hline$\Delta \mathrm{P}$ & $-1.045(-5.16) * * *$ & $-1.047(-5.06) * * *$ \\
\hline \multicolumn{3}{|l|}{ Eggs } \\
\hline $\mathrm{Y}$ & $-0.713(3.85)$ *** & $-0.750(-4.19) * * *$ \\
\hline$\Delta \mathrm{Y}$ & $-1.803(-6.04) * * *$ & $-1.968(-6.34) * * *$ \\
\hline $\mathrm{P}$ & $-0.068(-1.30)$ & $-0.335(-2.06)$ \\
\hline$\Delta \mathrm{P}$ & $-1.103(-5.47) * * *$ & $-1.117(-5.42) * * *$ \\
\hline \multicolumn{3}{|l|}{ Milk } \\
\hline $\mathrm{Y}$ & $0.132(1.06)$ & $-0.298(-1.52)$ \\
\hline$\Delta \mathrm{Y}$ & $-0.833(-3.75) * * *$ & $-1.956(-3.93) * * *$ \\
\hline $\mathrm{P}$ & $0.063(1.01)$ & $-0.332(-2.16)$ \\
\hline$\Delta \mathrm{P}$ & $-0.881(-4.08) * * *$ & $-0.984(-4.24) * * *$ \\
\hline
\end{tabular}
PRICES FOR THE SELECTED COMMODITIES

TABLE II

COINTEGRATION TESTS: ENGLE-GRANGER AND JOHANSEN FOR THE SELECTED COMMODITIES

\begin{tabular}{lllllr}
\hline \hline & \multicolumn{3}{c}{ Engle-Granger Test } & \multicolumn{2}{c}{ Johansen Test } \\
\cline { 2 - 6 } & $\begin{array}{l}\text { ADF } \\
\text { without } \\
\text { constant } \\
\text { and } \\
\text { trend }\end{array}$ & $\begin{array}{l}\text { ADF } \\
\text { with } \\
\text { trend and } \\
\text { constant }\end{array}$ & $\begin{array}{l}\text { Eigenvalue } \\
\text { Test }\end{array}$ & Trace Test \\
\hline Cow & -0.476 & -0.243 & 0 & 0.626 & $34.471(26.593)$ \\
meat & $(-3.506)$ & $(-2.685)$ & 1 & 0.253 & $7.877(7.877)$ \\
Sheep & -0.380 & -1.763 & 0 & 0.682 & $35.532(30.934)$ \\
meat & $(-2.265)$ & $(-5.715)$ & 1 & 0.156 & $4.597(4.597)$ \\
& -0.569 & -0.768 & 0 & 0.440 & $20.090(15.696)$ \\
Eggs & $(-4.124)$ & $(-4.371)$ & 1 & 0.150 & $4.394(4.394)$ \\
& -0.068 & -0.289 & 0 & 0.331 & $11.589(8.471)$ \\
Milk & $(-0.783)$ & $(-1.823)$ & 1 & 0.138 & $3.118(3.118)$ \\
\hline \hline
\end{tabular}

Tables III and IV shows the results of the long-run (equation 1) and the VECM regression estimates (equation 2) for supply response to changes in real prices. Both the short and long run estimates as well as diagnostics are presented. All the estimated coefficients have the expected signs. The magnitude of the coefficient of determination (R2), and the F statistics show the equations' goodness of fit and significance of estimated relationships.

The error correction coefficients, which measures the speed of adjustment towards long-run equilibrium carries the 
expected negative sign and it is highly significant at the $1 \%$ level. The short-run effect of price has significant at $5 \%$ level. This may confirm the assumption that the short-run supply response is low.

Results show that the short-run price elasticities are low in cow and sheep meat sectors (8.7 and $8 \%$ respectively), while their respective long-run elasticities are 16.5 and 10.5, whereas eggs and milk have very high short-run price elasticities (82 and $90 \%$ respectively) with long-run elasticities of 40 and 46 respectively. The error correction coefficient, reflecting the speed of adjustment towards the long-run equilibrium, is statistically significant and have the expected negative sign. Its estimates are 12.7 for cow meat, 33.5 for sheep meat, 46.7 for eggs and 8.4 for milk. It seems that cow meat and milk producers have a weak feedback of about $12.7 \%$ and $8.4 \%$ respectively of the previous year's disequilibrium from the long-run price elasticity, whereas sheep meat and eggs producers adjust to correct long run disequilibrium with a high speed of adjustment $(33.5 \%$ and $46.7 \%$ respectively). Furthermore, the trend shows significant effects in long-run perspective. It has higher effects in dairy commodities (cow meat and milk), whereas it has very low impact in sheep and eggs sectors.

TABLE III

LONG-RUN REGRESSION ESTIMATES OF THE SUPPLY RESPONSE FOR LIVESTOCK COMMODITIES IN ALGERIA (1966-2018)

\begin{tabular}{lrrrr}
\hline \hline & Cow meat & Sheep meat & Eggs & Milk \\
\hline const. & 0.683 & 1.665 & 4.236 & 2.020 \\
& $(1.40)$ & $(5.7)^{* * *}$ & $(3.7)^{* * *}$ & $(1.0)$ \\
$P_{t-1}$ & 0.165 & 0.105 & 0.400 & 0.461 \\
& $(0.53)$ & $(0.45)$ & $(0.99)$ & $(0.89)$ \\
$T$ & 0.218 & 0.024 & 0.154 & 0.491 \\
& $(1.41)^{*}$ & $(1.41)^{*}$ & $(1.63)^{*}$ & $(2.4)^{* *}$ \\
& & & & \\
$\mathrm{R}^{2}$ & 0.895 & 0.226 & 0.207 & 0.946 \\
Adj. ${ }^{2}$ & 0.881 & 0.125 & 0.103 & 0.937 \\
$\mathrm{~F}$ & $65.562^{* * *}$ & $62.243^{* * *}$ & $92.002^{* * *}$ & $101.21^{* * *}$ \\
\hline \hline
\end{tabular}

TABLE IV

SHORT-RUN-VECM OF THE SUPPLY RESPONSE FOR LIVESTOCK COMMODITIES IN ALGERIA (1966-2018)

\begin{tabular}{|c|c|c|c|c|}
\hline & Cow meat & Sheep meat & Eggs & Milk \\
\hline \multirow[t]{2}{*}{ const. } & 0.908 & -1.048 & 1.134 & 2.040 \\
\hline & (1.46) & $(-0.03)$ & $(2.1) * * *$ & $(1.79)^{*}$ \\
\hline \multirow[t]{2}{*}{$\Delta P$} & -0.087 & -0.080 & -0.820 & 0.905 \\
\hline & $(-3.8) * * *$ & $(-0.7)$ & $(-0.26)$ & $(0.08)$ \\
\hline \multirow[t]{2}{*}{$T$} & 0.395 & 0.003 & -0.057 & 0.286 \\
\hline & $(3.7)^{* * *}$ & $(0.25)$ & $(-0.56)$ & $(2.4)^{* *}$ \\
\hline \multirow{2}{*}{$E C(\lambda)$} & -0.127 & -0.335 & -0.467 & -0.084 \\
\hline & $(-2.9) * * *$ & $(-1.8)^{* * *}$ & $(-4.2) * * *$ & $(-2.2)^{* *}$ \\
\hline $\mathrm{R}^{2}$ & 0.526 & 0.687 & 0.462 & 0.294 \\
\hline Adj. $R^{2}$ & 0.464 & 0.646 & 0.392 & 0.170 \\
\hline D.W. & 1.948 & 2.152 & 2.113 & 1.869 \\
\hline
\end{tabular}

\section{CONCLUSION}

Present paper estimates the aggregate supply response of four livestock commodities in Algerian agricultural sector. In this study, cow and sheep meat, eggs and milk were selected as main livestock food products in the Algerian consumption pattern. Data was taken for the period 1966 to 2018 provided by the FAO statistical database on quantity produced and prices. The paper aimed to investigate the extent that Algerian livestock farmers do respond to economic incentives. Time series analytic techniques (cointegration analysis and error correction model) were used to undermine the quantitative effects of the price of the selected livestock production.

Base on the result of this study, price is an influential factor motivating farmers to respond in supply of livestock production. And the price has a positive impact in terms of influencing livestock farmers to react in a price change by responding with increase in production to a price change, so that to increase the aggregate production. It is therefore fair to conclude that distorted prices, poor technology development, low credit facilities and other factors are the bane of agricultural growth in Algeria.

The implication of this is that much more in-depth research is needed to identify those factors that affect supply and to describe the effect of factors that shift livestock supply on the response to price incentives. This could provide valuable information for government in its use of appropriate policy measures and instruments.

One of the limitations of this study was lack of sufficient data, which restricted the study to a relatively high level of aggregation of agricultural production. For this reason, weather conditions, price risks, technology use and structural breaks were not considered (although the trends in the series do not reflect faithfully and precisely such factors). All these factors may lead to underestimation of aggregate supply response. Any of these limitations may explain the nonsignificance of some of the variables.

\section{REFERENCES}

[1] A. Tripathi and A.R. Prasad (2009). Estimation of agricultural supply response by cointegration approach. The Indian Economic Journal, 57(1): 106-131.

https://doi.org/10.1177/0019466220090106

[2] A. Ghafouri (1988). Supply response in the Algerian agriculture. Dissertation, University of Leicester, UK.

[3] M.A. Benmehaia (2021). Aggregate supply response in Algerian agriculture: The error correction model applied to selected crops. New Medit, 20(1).

[4] M.A. Benmehaia and A. Oulmane (2020). Analyse de la réponse de l'offre agrégée face à la volatilité des prix des produits agricoles en Algérie : cas de la filière pomme de terre. Cahiers de CREAD, 37(1).

[5] A. McKay, O. Morrissey and C. Vaillant (1999). Aggregate supply response in Tanzanian agriculture. Journal of International Trade \& Economic Development, 8(1): 107-123. https://doi.org/10.1080/09638199900000008

[6] D. Hallam and R. Zanoli (1993). Error correction models and agricultural supply response. European Review of Agricultural Economics, 20(2): 151-166. https://doi.org/10.1093/erae/20.2.151

[7] Z.G. Alemu, K. Oosthuizen and H.V. Schalkwyk (2003). Grain-supply response in Ethiopia: An error-correction approach. Agrekon, 42(4): 389-404. https://doi.org/10.1080/03031853.2003.9523631

[8] Mbaga M. and B.T. Coyle (2003). Beef Supply Response under Uncertainty: An Autoregressive Distributed Lag Model. Journal of Agricultural and Resource Economics, 28(3):519-539.

[9] W-M. Ndayitwayeko, M.O. Odhiambo, P.M. Nyangweso and M. Korir (2012). Determinants of beef meat supply in Burundi: A vector error correction model approach applied to structural Nerlov paradigm. The 8th AFMA Congress. No. 304-2016-4799, pp. 425-436 